\title{
PENGARUH NARSISME KLIEN, AUDIT FEE, INDEPENDENSI, SKEPTISME PROFESIONAL, DAN INTERLOCK AUDITOR EKSTERNAL TERHADAP AUDIT JUDGEMENT DALAM PENDETEKSIAN KECURANGAN LAPORAN KEUANGAN (STUDI KASUS PADA KAP DI MANADO)
}

\author{
Claudia Wanda Melati Korompis ${ }^{1}$, Lady Diana Latjandu ${ }^{2}$ \\ ${ }^{1,2}$ Jurusan Akuntansi, Fakultas Ekonomi dan Bisnis, Universitas Sam Ratulangi, Jl. Kampus Kleak Bahu, \\ Manado, 95114, Indonesia \\ email : wanda_korompis@yahoo.co.id ${ }^{(1)}$ \\ ladydianalatjandu@gmail.com ${ }^{(2)}$
}

\begin{abstract}
A material misstatement is the beginning of a fraud that can not be detected by an auditor and may have negative effects on the financial reporting process. The Internal factors related to the audit work environment in this research are audit fees, Independence, professional skepticism and Auditor Interlock. Sometimes, the amount of audit fee makes an auditor in a dilemma position on giving the opinion about the fairness of financial statements relating to the interests of many parties. The other factor which making a dilemma problem is Independence. Independence should be maintained by an auditor to provide a neutral assessment of the financial statements. Researchers also choose professional skepticism as things that need to be developed in order to reduce the adverse effects of fraudulent financial statement. The last Internal factor in this research is Auditor Interlock that may help auditor to get all disclosure that they're needed. The unique external factor is client narcissism. Narcissism is known as a distorted personal characteristic that may obstruct an auditor's opinion statement according to the scope of the examination.

The samples are all external auditors in KAP which operating in Manado area. Multiple linear regression analysis is an analysis thecnique that used in this research. Instrument in this research is questionnaire and processed using SPSS program.

The results of this study indicate that the Audit fee and Independence have a significant effect on audit judgment. While Client Narsism, Professional Skepticism, and Interlock external auditors have no significant effect on audit judgment.
\end{abstract}

Key Words: Narcissism, Fee, Independence, Skepticism, Interlock, Judgment.

\section{PENDAHULUAN}

Profesi Akuntan Publik merupakan salah satu profesi kepercayaan Masyarakat, yang diharapkan memberikan penilain yang tidak memihak atas asersi yang disajikan manajemen perusahan. Kualitas dari suatu audit menjadi tolak ukur Kualitas dari KAP itu sendiri. Profesi Akuntan Publik bertanggungjawab menaikkan tingkat keandalan laporan keuangan perusahaan-perusahaan. Laporan audit merupakan alat yang digunakan oleh auditor untuk mengkomunikasikan hasil auditnya kepada masyarakat. Salah saji yang material merupakan awal terjadinya kecurangan yang tidak dapat terdeteksi oleh suatu pengauditan dan dapat memberikan efek yang merugikan serta cacat bagi proses pelaporan keuangan. Adanya kecurangan berakibat serius dan membawa banyak kerugian. Kasus-kasus skandal akuntansi dalam tahun-tahun belakangan ini memberikan bukti lebih jauh tentang kegagalan audit yang membawa akibat serius bagi masyarakat bisnis. Pendeteksian kecurangan bukan hal mudah untuk dilaksanakan oleh auditor eksternal. Berbagai faktor internal dan eksternal berpengaruh terhadap pengungkapan salah saji material tersebut. Pengalaman auditor dan proses audit yang lengkap tidaklah cukup untuk dijadikan standar seorang auditor dapat mendeteksi suatu kecurangan. 
Faktor internal yang berhubungan dengan lingkungan pekerjaan audit adalah fee audit. Besaran fee inilah yang kadang membuat seorang auditor berada di dalam posisi dilematis, di satu sisi auditor harus bersikap independen dalam memberi opini mengenai kewajaran laporan keuangan yang berkaitan dengan kepentingan banyak pihak, namun disisi lain auditor juga harus bisa memenuhi tuntutan yang diinginkan oleh klien yang membayar fee atas jasanya, agar kliennya puas dengan pekerjaannya dan tetap menggunakan jasanya diwaktu yang akan datang. Oleh karena itu penting bagi suatu KAP untuk tidak menjadikan Fee Audit sebagai alat persaingan dengan tujuan untuk kepentingan pribadi (Purba : 2013).

Kualitas suatu audit juga ditentukan oleh tingkat independensi auditor. Sulitnya independensi dalam bersikap di lingkungan KAP disebabkan karena beberapa faktor, yakni faktor hubungan keluarga berupa suami/istri, saudara sedarah semenda dengan klien, faktor hubungan usaha dan keuangan dengan klien, keuntungan dan kerugian terkait usaha dengan klien, dan faktor keterlibatan dalam usaha yang tidak sesuai. Auditor di lingkungan KAP semakin sulit untuk bersikap independen karena kuatnya unsur kekerabatan. Independensi merupakan salah satu komponen etika selain integritas dan objektivitas yang harus dijaga oleh seorang auditor.

Penilaian kecurangan adalah proses yang sistematis dan melibatkan pertimbangan professional (Arens, Erens, Beasley, 2014). Salah satu faktor internal yang erat dengan kemampuan membuat penilaian adalah skeptisme professional. Pengetahuan dan karakter yang dimiliki auditor memiliki kaitan dengan tingkat skeptisme profesional auditor (Nelson, 2009). Oleh karena itu, auditor perlu mengembangkan skeptisme profesionalnya dalam rangka mengurangi dampak buruk dari kecurangan pelaporan keuangan. Terutama bagi auditor yang selama karirnya belum pernah menemui kecurangan. (Winardi dan Permana : 2015).

Auditor yang kritis juga dihasilkan dari ruang lingkup pekerjaannya. Semakin besar suatu KAP berarti pengalaman kerja seorang auditor semakin banyak sehingga memungkinkan auditor untuk mengembangkan praktik kerjanya. Disinilah terjadi interlock Auditor eksternal. Keahlian dan pengalaman yang dimiliki auditor di perusahaan lain dapat membantu mempengaruhi kualitas judgment laporan keuangan yang diauditnya.

Faktor eksternal juga memiliki pengaruh bagi pengambilan keputusan seorang auditor. Faktor internal yang unik adalah Narsisme klien. Narsisme berkembang pada lingkungan yang memberikan penghargaan karena adanya perhatian positif dari orang lain kepada seseorang dengan narsisme. Karakter narsisme merupakan karakter yang dapat dikaitkan dengan penilaian risiko kecurangan. Seseorang dengan narsisme cenderung melakukan perilaku menyimpang karena karakternya yang mengharapkan tanggapan positif dari orang lain (Winardi dan Permana : 2015).

Kantor Akuntan Publik di Manado memiliki reputasi yang baik. Tidak jarang berbagai penawaran untuk menggunakan jasa KAP dari Manado untuk mengaudit laporan keuangan perusahaan yang berada di luar wilayah ini. Sebagai salah satu wilayah yang memiliki KAP dengan reputasi yang baik, dirasa sangat penting untuk tetap mempertahankan kualitas audit yang ada apalagi meningkatkannya.

Tujuan penelitian ini adalah sebagai berikut:

1. Untuk mengetahui pengaruh Narsisme Klien terhadap Audit Judgement dalam Pendeteksian Kecurangan Laporan Keuangan

2. Untuk mengetahui pengaruh Audit Fee terhadap Audit Judgement dalam Pendeteksian Kecurangan Laporan Keuangan

3. Untuk mengetahui pengaruh Independensi terhadap Audit Judgement dalam Pendeteksian Kecurangan Laporan Keuangan

4. Untuk mengetahui pengaruh Skeptisme Profesional terhadap Audit Judgement dalam Pendeteksian Kecurangan Laporan Keuangan 


\section{Untuk mengetahui pengaruh Interlock Auditor Eksternal terhadap Audit Judgement dalam Pendeteksian Kecurangan Laporan Keuangan}

\section{TINJAUAN PUSTAKA}

\subsection{Narsisme Klien}

Tingkat narsisme seorang klien akan dinilai oleh auditor sebagai suatu bentuk kepribadian yang dapat melakukan rasionalisasi terhadap kecurangan terjadi (Johnson, Kuhn, Apostolou, Hassel, 2013). Schwartz (1991) dalam Amemic dan Craig (2010) menyebutkan bahwa akuntansi sebagai bagian dari sistem keuangan, menawarkan "peluang narsisme" yang lebih besar daripada fungsi manajemen yang lain misalnya bagian operasi. Menurut Rijsenbilt dan Commandeur (2013) terdapat hubungan positif antara narsisme dengan tindakan curang. Hal ini akan berbahaya apabila seseorang dengan narsisme tersebut memiliki kewenangan yang dapat mempengaruhi kebijakan bawahannya (Amemic dan Craig, 2010). Penelitian Johnson, et al.(2013) menyajikan kesimpulan mengenai adanya peningkatan penilaian risiko kecurangan yang dilakukan oleh auditor ketika manajer menampilkan sikap narsisme. Sehingga narsisme dari seorang manajer klien dapat digunakan sebagai salah satu pengukuran dalam penilaian risiko kecurangan (Johnson, et al., 2013).

\subsection{Audit Fee}

Sukrisno (2012:18) mendefinisikan Fee Audit sebagai besarnya biaya tergantung antara lain resiko penugasan ,kompleksitas jasa yang diberikan, tingkat keahlian yang diperlukan untuk melaksanakan jasa tersebut, struktur biaya KAP yang bersangkutan dan pertimbangan professional lainya.

Sukrisno (2012:46) lebih lanjut lagi menyatakan bahwa Anggota KAP tidak diperkenankan mendapatkan klien dengan cara menawarkan fee yang dapat berakibat pada kualitas audit yang akan dihasilkan.

Sukrisno (2012:18) menyatakan bahwa indikator dari fee audit diukur dari :

1. Resiko penugasan

2. Kompleksitas jasa yang diberikan

3. Struktur biaya kantor akuntan publik yang bersangkutan dan pertimbangan profesi lainnya

\section{Ukuran KAP}

\subsection{Independensi}

Mayangsari dalam Rapina, Saragi, dan Carolina (2010) menyebutkan bahwa independensi adalah sikap yang diharapkan dari seorang auditor untuk tidak mempunyai kepentingan pribadi dalam pelaksanaan tugasnya, yang bertentangan dengan prinsip integritas dan objektivitas. Setiap akuntan harus memelihara integritas dan objektivitas dalam tugas profesionalnya dan setiap auditor harus independen dari semua kepentingan yang bertentangan atau pengaruh yang tidak layak. Adanya independensi dan objektivitas yang dimiliki auditor untuk dapat melakukan pekerjaannya secara bebas dan objektif, memungkinkan auditor membuat pertimbangan penting secara mental dan tidak menyimpang. Sulitnya independensi dalam bersikap di lingkungan KAP disebabkan karena beberapa faktor, yakni faktor hubungan keluarga berupa suami/istri, saudara sedarah semenda dengan klien, faktor hubungan usaha dan keuangan dengan klien, keuntungan dan kerugian terkait usaha dengan klien, dan faktor keterlibatan dalam usaha yang tidak sesuai.

\subsection{Skeptisme Profesional}

Kurangnya skeptisme dari auditor akan menyebabkan ketidakmampuan auditor untuk melihat adanya peningkatan risiko yang telah terjadi (Hammersley, 2011). Auditor harus bersikap kritis terhadap seluruh bukti selama proses audit, baik dari fase pengumpulan bukti hingga fase evaluasi bukti audit. Hurtt (2010b) mendefinisikan skeptisme profesional sebagai konstruk multi-dimensional yang menandakan adanya kecenderungan dari setiap individu 
untuk menunda membuat kesimpulan hingga memperoleh bukti yang cukup untuk mendukung salah satu alternatif penjelasan dibandingkan yang lain. Hurtt, et al.(2010a) menyampaikan bahwa karakter skeptisme dari auditor akan mempengaruhi perilaku auditor, yaitu penilaian bukti dan pembuatan argumentasi alternatif, dimana penilaian bukti tersebut terdiri dari pencarian informasi tambahan oleh auditor, deteksi informasi yang berkontradiksi, dan kesalahan yang tidak disengaja.

\subsection{Interlock Auditor Eksternal}

Hubungan interlock antar perusahaan, bisa juga terjadi dengan auditor eksternal, yang bekerja untuk beberapa perusahaan. Braam dan Borghans (2014) menyatakan bahwa ketika perusahaan memiliki hubungan interlock, baik memiliki keterkaitan antara dewan direksi, dewan komisaris maupun auditor eksternalnya, ada kemungkinan kesamaan indikator pengungkapan sukarela antar perusahaan yang terkait. Auditor eksternal dapat mempengaruhi keputusan dalam pengungkapan sukarela perusahaan di laporan tahunan (Braam dan Borghans, 2014).

Adanya hubungan interlock dapat menciptakan kerjasama antar perusahaan, seperti pertukaran informasi dan pengetahuan sehingga diharapkan dengan melalui informasi ini, perusahaan dapat meningkatkan keunggulan kompetitifnya dan mampu menghadapi persaingan di pasar menurut Haunschild dan Beckman dalam Sari dan Juliarto (2016). Hubungan interlock, diharapkan dapat menjadi sarana bagi perusahaan untuk mengurangi ketidakpastian dan memudahkan dalam mengakses sumber daya menurut Borgatti dan Foster dalam Sari dan Juliarto (2016).

\subsection{Audit Judgement}

Judgement auditor dapat didefinisikan sebagai kebijakan auditor dalam menentukan pendapat mengenai hasil auditnya yang mengacu pada pembentukan suatu gagasan, pendapat atau perkiraan suatu obyek, peristiwa, status atau jenis peristiwa lain (Irmawan : 2011, dikutip dari Jamilah dkk.). Sieggel dalam Irmawan (2011) menyatakan bahwa Judgement yang merupakan bagian penting dari professional, merupakan hasil dari berbagai faktor seperti pendidikan, budaya dan yang lainnya. Tetapi elemen yang paling signifikan dan mengontrolnya adalah pengalaman. Judgement adalah perilaku yang paling dipengaruhi oleh persepsi situasi. Auditor sebagai manusia tidak berorientasi pada probabilitas, biasanya mereka menyadarkan diri pada Judgement heuristic yang biasanya berasal dari pengalaman.

\subsection{Fraud dalam Laporan Keuangan}

Loebbecke et al. Dalam Koroy (2008) menyatakan bahwa kecurangan lebih sulit untuk dideteksi karena biasanya melibatkan penyembunyian (concealment). Penyembunyian itu terkait dengan catatan akuntansi dan dokumen yang berhubungan, dan hal ini juga berhubungan dengan tanggapan pelaku kecurangan atas permintaan auditor dalam melaksanakan audit. Koroy (2008) menunjukkan bahwa sebagian besar auditor (dalam penelitian ini menggunakan partner) tidak mampu mendeteksi kecurangan dengan baik. Walaupun motivasi, pelatihan dan pengalamannya memadai, para partner yang diuji dapat dikelabui oleh bingkai dari manajemen klien. relevan dengan kecurangan.

\section{METODE PENELITIAN}

\subsection{Jenis dan Sumber Data}

Jenis penelitian ini adalah penelitian dengan analisis kuantitatif. Jenis data yang dipergunakan adalah data kualitatif dan diukur menggunakan skala ordinal dengan jenis skala Likert 1-5 agar dapat diproses lebih lanjut. Data kualitatif sebagai data utama dalam penelitian ini yaitu berbentuk uraian melalui respon tertulis (kuesioner). Sebagai penunjang juga digunakan data kuantitatif yaitu data yang disajikan dalam bentuk angka-angka baik yang didapat di literatur-literatur perpustakaan pribadi maupun umum dan data dari internet. 


\subsection{Sampel dan Teknik Pengambilan Sampel}

Populasi dalam penelitian ini adalah semua KAP yang menjalankan operasinya di Manado yaitu KAP Drs.Auly, dan KAP DR.J.Sondakh \& DR.G.Nangoi. Teknik pengambilan sampel menggunakan judgement sampling dengan sayarat yaitu semua auditor baik tetap maupun tidak tetap yang telah bekerja di KAP minimal telah mengaudit 2 perusahaan. Jumlah populasi adalah 24 responden dan memenuhi syarat untuk dijadikan sampel. Kuesioner telah diisi dan yang dikembalikan berjumlah 23 kuesioner.

\subsection{Metode Analisis}

Adapun serangkaian uji yang dilakukan dalam penelitian ini adalah sebagai berikut :

a. Uji Validitas dan Reliabilitas

b. Uji Asumsi Klasik

Uji asumsi klasik berupa uji normalitas, uji heterokedastisitas, dan uji multikolinearitas.

c. Koefisien Korelasi dan Koefisien Determinasi

d. Regresi Linear Berganda

Melakukan interpretasi model regresi linier dengan persamaan berikut :

$Y=\alpha+\beta_{1} X_{1}+\beta_{2} X_{2}+\beta_{3} X_{3}+\beta_{4} X_{4}+\beta_{5} X_{5}+\varepsilon$

Dimana :

Y : Audit Judgement dalam Pendeteksian Kecurangan Laporan Keuangan

$\alpha$ : Konstanta yang menyatakan jika tidak ada variabel Narsisme Klien, Audit Fee, Independensi, Skeptisme Profesional, dan Interlock Auditor Eksternal maka skor Audit Judgement dalam Pendeteksian Kecurangan Laporan Keuangan akan sebesar a satuan.

$\beta_{1} \quad$ : Koefisien regresi Narsisme Klien

$\mathrm{X}_{1}$ : Narsisme Klien

$\beta_{2}$ : Koefisien regresi Audit Fee

$\mathrm{X}_{2}$ : Audit Fee

$\beta_{3}:$ Koefisien regresi Independensi

$\mathrm{X}_{3} \quad$ : Independensi

$\beta_{4}:$ Koefisien regresi Skeptisme Profesional

$\mathrm{X}_{4}$ : Skeptisme Profesional

$\beta_{5}$ : Koefisien regresi Interlock Auditor Eksternal

$\mathrm{X}_{5} \quad$ : Interlock Auditor Eksternal

$\varepsilon \quad$ : Error.

e. Uji F dan Uji t

Kriteria pengujian yaitu jika $F_{\text {hitung }} / t_{\text {hitung }}>F_{\text {hitung }} / t_{\text {tabel }}$ atau apabila signifikan $<0,05$ maka $\mathrm{H}_{0}$ ditolak berarti variabel bebas berpengaruh signifikan terhadap variabel terikat, dan sebaliknya.

\section{HASIL ANALISIS DAN PEMBAHASAN}

4.1 Hasil Analisis

a. Uji Validitas dan Reliabilitas Data

Hasil uji validitas dan reliabilitas terhadap sampel surrogate dalam hal ini mahasiswa S1 dan S2 Akuntansi dengan menggunakan SPSS 17 sebagai berikut. 
Tabel 1. Hasil Uji Validitas dan Reliabilitas

\begin{tabular}{|c|c|c|c|c|c|}
\hline Variabel & Kode & $\begin{array}{c}\text { Corrected Item-Total } \\
\text { Correlation }\end{array}$ & Keputusan & $\begin{array}{c}\text { Koefisien } \\
\text { Cronbach Alpha }\end{array}$ & Keputusan \\
\hline \multirow{5}{*}{$\begin{array}{l}\text { Narsisme Klien } \\
\text { (x1) }\end{array}$} & $\mathrm{P} 1 \mathrm{X} 1$ & 0.309 & Valid & \multirow{5}{*}{0.752} & \multirow[t]{5}{*}{ Reliabel } \\
\hline & $\mathrm{P} 2 \mathrm{X} 1$ & 0.700. & Valid & & \\
\hline & $\mathrm{P} 3 \mathrm{X} 1$ & 0.565 & Valid & & \\
\hline & $\mathrm{P} 4 \mathrm{X} 1$ & 0.703 & Valid & & \\
\hline & P5X1 & 0.418 & Valid & & \\
\hline \multirow[t]{5}{*}{ Audit Fee (x2) } & $\mathrm{P} 1 \mathrm{X} 2$ & 0.589 & Valid & \multirow[t]{5}{*}{0.720} & \multirow[t]{5}{*}{ Reliabel } \\
\hline & $\mathrm{P} 2 \mathrm{X} 2$ & 0.311 & Valid & & \\
\hline & $\mathrm{P} 3 \mathrm{X} 2$ & 0.592 & Valid & & \\
\hline & $\mathrm{P} 4 \mathrm{X} 2$ & 0.400 & Valid & & \\
\hline & $\mathrm{P} 5 \mathrm{X} 2$ & 0.303 & Valid & & \\
\hline \multirow{5}{*}{$\begin{array}{l}\text { Independensi } \\
\text { (x3) }\end{array}$} & $\mathrm{P} 1 \mathrm{X} 3$ & 0.545 & Valid & \multirow[t]{5}{*}{0.763} & \multirow[t]{5}{*}{ Reliabel } \\
\hline & $\mathrm{P} 2 \mathrm{X} 3$ & 0.679 & Valid & & \\
\hline & $\mathrm{P} 3 \mathrm{X} 3$ & 0.533 & Valid & & \\
\hline & $\mathrm{P} 4 \mathrm{X} 3$ & 0.415 & Valid & & \\
\hline & P5X3 & 0.668 & Valid & & \\
\hline \multirow{5}{*}{$\begin{array}{l}\text { Skeptisme } \\
\text { Profesional } \\
(\mathrm{x} 4)\end{array}$} & $\mathrm{P} 1 \mathrm{X} 4$ & 0.582 & Valid & \multirow[t]{5}{*}{0.702} & \multirow[t]{5}{*}{ Reliabel } \\
\hline & $\mathrm{P} 2 \mathrm{X} 4$ & 0.434 & Valid & & \\
\hline & $\mathrm{P} 3 \mathrm{X} 4$ & 0.307 & Valid & & \\
\hline & $\mathrm{P} 4 \mathrm{X} 4$ & 0.389 & Valid & & \\
\hline & P5X4 & 0.385 & Valid & & \\
\hline \multirow{5}{*}{$\begin{array}{l}\text { Interlock } \\
\text { Auditor } \\
\text { Eksternal (x5) }\end{array}$} & P1X5 & 0.504 & Valid & \multirow[t]{5}{*}{0.769} & \multirow[t]{5}{*}{ Reliabel } \\
\hline & $\mathrm{P} 2 \mathrm{X} 5$ & 0.786 & Valid & & \\
\hline & P3X5 & 0.604 & Valid & & \\
\hline & P4X5 & 0.544 & Valid & & \\
\hline & P5X5 & 0.548 & Valid & & \\
\hline \multirow{5}{*}{$\begin{array}{l}\text { Audit } \\
\text { Judgement (Y) }\end{array}$} & P1Y & 0.644 & Valid & \multirow[t]{5}{*}{0.724} & \multirow[t]{5}{*}{ Reliabel } \\
\hline & $\mathrm{P} 2 \mathrm{Y}$ & 0.473 & Valid & & \\
\hline & P3Y & 0.311 & Valid & & \\
\hline & $\mathrm{P} 4 \mathrm{Y}$ & 0.506 & Valid & & \\
\hline & P5Y & 0.359 & Valid & & \\
\hline
\end{tabular}

\section{b. Uji Asumsi Klasik}

1. Uji Normalitas : Uji normalitas menunjukkan bahwa grafik Normal P-P of regression standardized residual memenuhi asumsi normalitas dimana menggambarkan penyebaran data di sekitar dan mengikuti arah garis diagonal grafik tersebut.

2. Uji Heteroskedastisitas : Titik-titik pada uji heteroskedastisitas tidak membentuk suatu pola yang jelas, serta titik-titik menyebar di atas dan di bawah angka 0 (nol) pada sumbu Y, hal ini membuktikan tidak terjadi heteroskedastisitas.
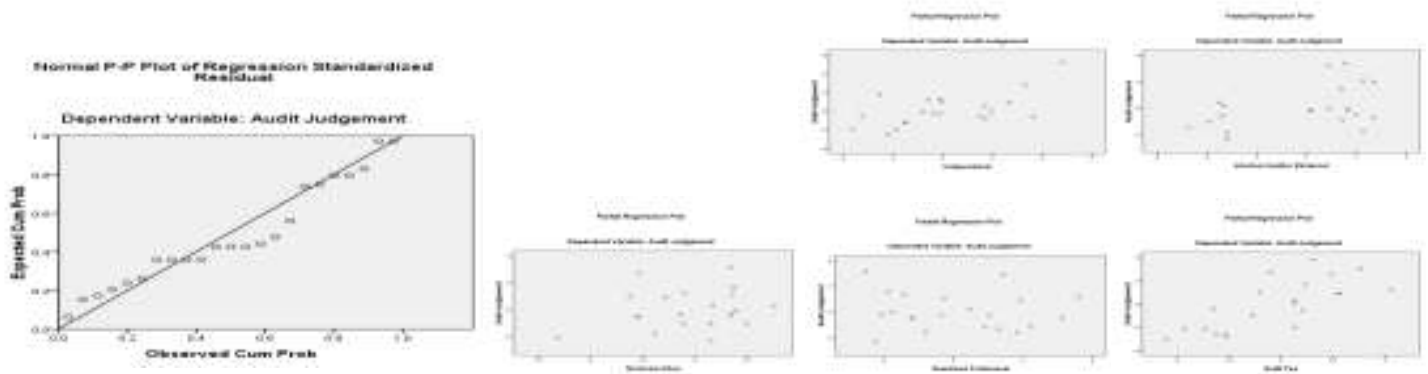

Gambar 1. Uji Normalitas dan Uji Heteroskedastisitas

3. Uji Multikolinearitas : Hasil dari perhitungan menghasilkan nilai VIF untuk variabel Narsisme Klien $\left(\mathrm{X}_{1}\right)$ adalah sebesar $1,471<10$ dan nilai tolerance 0,680 >0,10, Audit Fee $\left(\mathrm{X}_{2}\right)$ adalah sebesar 1,082 < 10 dan nilai tolerance $0,924>0,10$, Independensi $\left(\mathrm{X}_{3}\right)$ adalah sebesar 1,282 < 10 dan nilai tolerance $0,780>0,10$, Septisme Profesional $\left(\mathrm{X}_{4}\right)$ adalah sebesar 1,616 < 10 dan nilai tolerance 0,619 > 0,10, Interlock Auditor Eksternal 
$\left(\mathrm{X}_{5}\right)$ adalah sebesar $1,133<10$ dan nilai tolerance $0,883>0,10$. Maka dapat disimpulkan bahwa tidak terjadi gejala multikolinearitas dalam model penelitian ini.

\section{c. Koefisien Korelasi (r)}

Hasil olahan data menunjukkan bahwa variabel Narsisme Klien $\left(\mathrm{X}_{1}\right)$ mempunyai korelasi yang bersifat cukup, positif dan tidak signifikan dengan Audit Judgement (Y) hal ini ditunjukkan dengan nilai koefisien korelasi sebesar 0,298<0,500, hal ini berarti apabila Narsisme Klien $\left(\mathrm{X}_{1}\right)$ naik, maka Audit Judgement (Y) akan naik pula, demikian sebaliknya. Koefisien korelasi 0,298 bersifat cukup karena hubungannya akan lebih kuat apabila Auditor memiliki pengetahuan akan perilaku psikologi seseorang. Variabel Audit Fee $\left(\mathrm{X}_{2}\right)$ mempunyai korelasi yang bersifat kuat, positif dan signifikan dengan Audit Judgement (Y) hal ini ditunjukkan dengan nilai koefisien korelasi sebesar 0,689>0,500, hal ini berarti apabila Audit Fee $\left(\mathrm{X}_{2}\right)$ naik, maka Audit Judgement (Y) akan naik pula, demikian sebaliknya. Koefisien korelasi 0,689 bersifat kuat karena auditor sadar bahwa pekerjaannya dihadapkan dengan sebuah kontrak yang mengikat sehingga prinsip kehati-hatian semakin diperhatikan. Variabel Independensi $\left(\mathrm{X}_{3}\right)$ mempunyai korelasi yang bersifat kuat, positif dan signifikan dengan Audit Judgement (Y) hal ini ditunjukkan dengan nilai koefisien korelasi sebesar 0,589 $>0,500$, hal ini berarti apabila Independensi $\left(\mathrm{X}_{3}\right)$ naik, maka Audit Judgement (Y) akan naik pula, demikian sebaliknya. Koefisien korelasi 0,589 bersifat kuat karena Independensi membuat seorang auditor mampu bersifat objektif akan pekerjaan yang dilakukannya. Variabel Skeptisme Profesonal $\left(\mathrm{X}_{4}\right)$ mempunyai korelasi yang bersifat cukup, positif dan signifikan dengan Audit Judgement (Y) hal ini ditunjukkan dengan nilai koefisien korelasi sebesar 0,367 < 0,500, hal ini berarti apabila Skeptisme Profesonal $\left(\mathrm{X}_{4}\right)$ naik, maka Audit Judgement (Y) akan naik pula, demikian sebaliknya. Koefisien korelasi 0,367 bersifat cukup karena hubungannya akan lebih kuat apabila Auditor memiliki lebih banyak pengalaman mengaudit perusahaan, sehingga tingkat sensitifitas terhadap fraud lebih tinggi. Variabel Interlock auditor eksternal $\left(\mathrm{X}_{5}\right)$ mempunyai korelasi yang bersifat cukup, positif dan signifikan dengan Audit Judgement (Y) hal ini ditunjukkan dengan nilai koefisien korelasi sebesar 0,363 < 0,500, hal ini berarti apabila Interlock auditor eksternal $\left(\mathrm{X}_{5}\right)$ naik, maka Audit Judgement (Y) akan naik pula, demikian sebaliknya. Koefisien korelasi 0,363 bersifat cukup karena hubungannya akan lebih kuat apabila Auditor memiliki banyak keahlian, pengalaman serta hubungan kerjasama yang baik dengan perusahaan lain sehingga mampu melaporkan sejumlah disclosure dari auditee yang berpengaruh terhadap pelaporan keuangan.

\section{d. Koefisien Determinasi $\left(\mathbf{R}^{2}\right)$}

Besarnya nilai koefisien determinasi $\left(\mathrm{R}^{2}\right)$ terlihat dari nilai adjusted $R$ square karena penelitian ini memiliki lebih dari satu variabel bebas yaitu sebesar 0,685 atau 68,5\%, sedangkan 31,5\% dipengaruhi oleh time pressure, kompetensi dan faktor-faktor lainnya.

\section{e. Analisis Regresi Linear Berganda}

Persamaan regresi dari data yang diteliti sebagai berikut.

$$
Y=-5,186+0,097 X_{1}+0,523 X_{2}+0,468 X_{3}-0,054 X_{4}+0,252 X_{5}+\varepsilon
$$

Hasil regresi ini menunjukkan pengaruh beberapa variabel bebas terhadap variabel tergantung Audit Judgement. Nilai konstan sebesar -5,186 menunjukkan bahwa jika variabel Narsisme Klien, Audit Fee, Independensi, Skeptisme Profesional, dan Interlock Auditor Eksternal dianggap konstan atau sama dengan nol (0) maka Audit Judgement pada Kantor Akuntan Publik di Kota Manado adalah sebesar -5,186 satuan score (nilai negatif disini dapat dianggap sebagai nol).

Koefisien regresi $\mathrm{X}_{1}$ sebesar 0,097 mengartikan bahwa jika faktor Narsisme Klien meningkat sebesar 1 satuan score dari kondisi sebelumnya maka Audit Judgement pada Kantor Akuntan Publik di Kota Manado akan meningkat sebesar 0,097 satuan score dari kondisi sebelumnya dengan asumsi variabel lain $\left(\mathrm{X}_{2}, \mathrm{X}_{3}, \mathrm{X}_{4}\right.$, dan $\left.\mathrm{X}_{5}\right)$ yang diteliti tetap. 
Koefisien regresi $\mathrm{X}_{2}$ sebesar 0,523 mengartikan bahwa jika faktor Audit Fee meningkat sebesar 1 satuan score dari kondisi sebelumnya maka Audit Judgement pada Kantor Akuntan Publik di Kota Manado akan meningkat sebesar 0,523 satuan score dari kondisi sebelumnya dengan asumsi variabel lain $\left(\mathrm{X}_{1}, \mathrm{X}_{3}, \mathrm{X}_{4}\right.$, dan $\left.\mathrm{X}_{5}\right)$ yang diteliti tetap.

Koefisien regresi $\mathrm{X}_{3}$ sebesar 0,468 mengartikan bahwa jika faktor Independensi meningkat sebesar 1 satuan score dari kondisi sebelumnya maka Audit Judgement pada Kantor Akuntan Publik di Kota Manado akan meningkat sebesar 0,468 satuan score dari kondisi sebelumnya dengan asumsi variabel lain $\left(\mathrm{X}_{1}, \mathrm{X}_{2}, \mathrm{X}_{4}\right.$, dan $\left.\mathrm{X}_{5}\right)$ yang diteliti tetap.

Koefisien regresi $\mathrm{X}_{4}$ sebesar $-0,054$ mengartikan bahwa jika faktor Skeptisme Profesional meningkat sebesar 1 satuan score dari kondisi sebelumnya maka Audit Judgement pada Kantor Akuntan Publik di Kota Manado akan menurun sebesar 0,054 satuan score dari kondisi sebelumnya dengan asumsi variabel lain $\left(\mathrm{X}_{1}, \mathrm{X}_{2}, \mathrm{X}_{3}\right.$, dan $\left.\mathrm{X}_{5}\right)$ yang diteliti tetap.

Koefisien regresi $\mathrm{X}_{5}$ sebesar 0,252 mengartikan bahwa jika faktor Interlock Auditor Eksternal meningkat sebesar 1 satuan score dari kondisi sebelumnya maka Audit Judgement pada Kantor Akuntan Publik di Kota Manado akan meningkat sebesar 0,252 satuan score dari kondisi sebelumnya dengan asumsi variabel lain $\left(\mathrm{X}_{1}, \mathrm{X}_{2}, \mathrm{X}_{3}\right.$, dan $\left.\mathrm{X}_{4}\right)$ yang diteliti tetap.

\section{f. Pengujian Hipotesis (Uji F)}

Hasil analisis menunjukkan nilai $F_{\text {hitung }}=10,590$. Angka ini lebih besar dari $F_{\text {tabel }}=2,81$ pada tingkat $\alpha=0,05$. Dengan demikian maka dapat disimpulkan bahwa $\mathrm{H}_{\mathrm{o}}$ ditolak dan $\mathrm{H}_{\mathrm{a}}$ diterima. Hal ini berarti, Narsisme Klien $\left(\mathrm{X}_{1}\right)$, Audit Fee $\left(\mathrm{X}_{2}\right)$, Independensi $\left(\mathrm{X}_{3}\right)$, Skeptisme Profesional $\left(\mathrm{X}_{4}\right)$, dan Interlock Auditor Eksternal $\left(\mathrm{X}_{5}\right)$ secara bersama-sama berpengaruh signifikan terhadap Audit Judgement (Y).

\section{g. Pengujian Hipotesis (Uji t)}

Nilai $t_{\text {hitung }}$ variabel $X_{1}$ adalah 0,710 . Dengan tingkat kepercayaan $5 \%$ pada derajat kebebasan $(\mathrm{N}-2)=23-2=21$, dapat diketahui nilai $t_{\text {tabel }}$ sebesar 2,079. Dengan demikian nilai $t_{\text {hitung }}<\mathrm{t}_{\text {tabel }}$, dengan nilai signifikan $0,488>0,05$. Hal ini berarti variabel Narsisme Klien $\left(\mathrm{X}_{1}\right)$ tidak berpengaruh signifikan terhadap Audit Judgement dalam pendeteksian kecurangan Laporan Keuangan pada Kantor Akuntan Publik di Kota Manado.

Nilai thitung variabel $\mathrm{X}_{2}$ adalah 4,617. Dengan tingkat kepercayaan $5 \%$ pada derajat kebebasan $(\mathrm{N}-2)=23-2=21$, dapat diketahui nilai $\mathrm{t}_{\text {tabel }}$ sebesar 2,079. Dengan demikian nilai $t_{\text {hitung }}>t_{\text {tabel }}$, dengan nilai signifikan $0,000<0,05$. Hal ini berarti variabel Audit Fee $\left(\mathrm{X}_{2}\right)$ berpengaruh signifikan terhadap Audit Judgement dalam pendeteksian kecurangan Laporan Keuangan pada Kantor Akuntan Publik di Kota Manado.

Nilai $t_{\text {hitung variabel }} X_{3}$ adalah 3,235. Dengan tingkat kepercayaan $5 \%$ pada derajat kebebasan $(\mathrm{N}-2)=23-2=21$, dapat diketahui nilai $\mathrm{t}_{\text {tabel }}$ sebesar 2,079. Dengan demikian nilai $t_{\text {hitung }}>t_{\text {tabel }}$, dengan nilai signifikan $0,005<0,05$. Hal ini berarti variabel Independensi $\left(\mathrm{X}_{3}\right)$ berpengaruh signifikan terhadap Audit Judgement dalam pendeteksian kecurangan Laporan Keuangan pada Kantor Akuntan Publik di Kota Manado.

Nilai $t_{\text {hitung }}$ variabel $X_{4}$ adalah $-0,291$. Dengan tingkat kepercayaan $5 \%$ pada derajat kebebasan $(\mathrm{N}-2)=23-2=21$, dapat diketahui nilai $\mathrm{t}_{\text {tabel }}$ sebesar 2,079. Dengan demikian nilai $t_{\text {hitung }}<t_{\text {tabel }}$, dengan nilai signifikan $0,775>0,05$. Hal ini berarti variabel Skeptisme Profesional $\left(\mathrm{X}_{4}\right)$ tidak berpengaruh signifikan terhadap Audit Judgement dalam pendeteksian kecurangan Laporan Keuangan pada Kantor Akuntan Publik di Kota Manado.

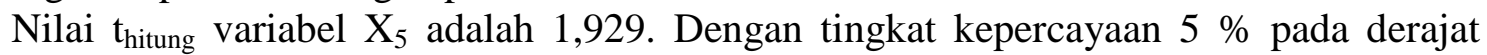
kebebasan $(\mathrm{N}-2)=23-2=21$, dapat diketahui nilai $\mathrm{t}_{\text {tabel }}$ sebesar 2,079. Dengan demikian nilai $t_{\text {hitung }}<\mathrm{t}_{\text {tabel}}$, dengan nilai signifikan $0,071>0,05$. Hal ini berarti variabel Interlock Auditor Eksternal $\left(\mathrm{X}_{5}\right)$ tidak berpengaruh signifikan terhadap Audit Judgement dalam pendeteksian kecurangan Laporan Keuangan pada Kantor Akuntan Publik di Kota Manado. 


\subsection{Pembahasan}

a. Narsisme Klien tidak berpengaruh terhadap Audit Judgement dalam pendeteksian kecurangan Laporan Keuangan pada Kantor Akuntan Publik di Manado

Kepribadian narsisme seorang klien cenderung dapat menyimpang karena sifat dasar dari narsisme adalah keinginan untuk mendapatkan tanggapan positif dari pihak lain. Jika keinginan untuk selalu mendapatkan tanggapan positif dari orang lain semakin meningkat, maka resiko akan kecurangan akan meningkat juga. Tingkat narsisme seorang klien akan dinilai oleh auditor sebagai suatu bentuk kepribadian yang dapat melakukan rasionalisasi terhadap kecurangan terjadi (Johnson, et al., 2013). Penelitian ini menunjukkan tidak ada pengaruh antara Narsisme Klien terhadap Audit Judgement. Hal ini didukung oleh pernyataan Johnson, et al.(2013) dimana dia menyatakan bahwa penilaian risiko kecurangan akan menjadi lebih tinggi ketika adanya motivasi kecurangan dari klien. Kecurangan hanya akan terjadi jika ada motivasi untuk berlaku curang dalam diri klien. Karena, seperti kita ketahui bersama bahwa semua orang sudah terlahir dengan sifat narsis, dan sifat ini dapat dikendalikan ke arah yang positif.

b. Audit Fee berpengaruh terhadap Audit Judgement dalam pendeteksian kecurangan Laporan Keuangan pada Kantor Akuntan Publik di Manado

Sukrisno (2012:18) menyatakan bahwa Fee merupakan imbalan berupa uang yang diterima oleh akuntan publik setelah melaksanakan jasa auditnya, besarnya tergantung dari resiko penugasan, kompleksitas jasa yang diberikan, tingkat keahlian yang diperlukan untuk melaksanakan jasa tersebut. Boone, Kurana dan Raman (2012) menyatakan bahwa kantor akuntan besar lebih mampu menyediakan dana besar untuk pelatihan dan teknologi audit. Sehingga Jasa atas Audit yang diberikan akan semakin mahal, karena mempekerjakan auditor-auditor yang berkompeten dan berkualitas. Dalam penelitian ini audit fee berpengaruh terhadap audit judgement karena dinilai bahwa, audit fee yang besar diakibatkan karena resiko serta reputasi KAP tersebut semakin tinggi, sehingga pemeriksaan mereka akan semakin baik pula.

c. Independensi berpengaruh terhadap Audit Judgement dalam pendeteksian kecurangan Laporan Keuangan pada Kantor Akuntan Publik di Manado

Kode Etik Akuntan yang dikutip Rapina, Saragi, dan Carolina (2010) disebutkan bahwa independensi adalah sikap yang diharapkan dari seorang auditor untuk tidak mempunyai kepentingan pribadi dalam pelaksanaan tugasnya, yang bertentangan dengan prinsip integritas dan objektivitas. Salah satu indikator terciptanya profesionalisme seorang auditor adalah sikap Independensi. Sikap Independensi tidaklah mudah untuk diterapkan oleh seorang auditor. Namun melalui sikap independen, seorang auditor akan dituntun dalam pelaksanaan tugas yang berkualitas. Hal inilah yang menjadi alasan mengapa faktor Independensi berpengaruh terhadap audit judgement dalam penelitian ini.

d. Skeptisme Profesional tidak berpengaruh terhadap Audit Judgement dalam pendeteksian kecurangan Laporan Keuangan pada Kantor Akuntan Publik di Manado

Kurangnya skeptisme dari auditor akan menyebabkan ketidakmampuan auditor untuk melihat adanya peningkatan risiko yang telah terjadi (Hammersley, 2011). Auditor harus bersikap kritis terhadap seluruh bukti selama proses audit, baik dari fase pengumpulan bukti hingga fase evaluasi bukti audit. Skeptisme Auditor datang mulai dari awal pemeriksaan. Namun jika tidak dioptimalkan dengan baik maka proses audit menjadi tidak efektif dan efisien. Penilaian terhadap kecurangan laporan keuangan, tidak dapat didasarkan pada asumsi awal semata, namun lebih kepada kedalaman suatu pemeriksaan. Oleh karena itu sikap skeptisme profesional tetap harus dilatih, karena jika skeptisme terlampau tinggi dan tidak dapat dikelola dengan baik, malah akan 
merugikan pihak auditor. Hal inilah yang menjadi pendapat peneliti mengapa skeptisme profesional tidak berpengaruh terhadap audit judgement dalam penelitian ini.

e. Interlock Auditor Eksternal tidak berpengaruh terhadap Audit Judgement dalam pendeteksian kecurangan Laporan Keuangan pada Kantor Akuntan Publik di Manado

Braam dan Borghans (2014), ketika perusahaan memiliki hubungan interlock, baik memiliki keterkaitan antara dewan direksi, dewan komisaris maupun auditor eksternalnya. Ada kemungkinan kesamaan indikator pengungkapan sukarela antar perusahaan yang terkait. Auditor eksternal dapat mempengaruhi keputusan dalam pengungkapan sukarela perusahaan di laporan tahunan. Hasil Penelitian ini menunjukkan bahwa tidak ada pengaruh antara Interlock Auditor Eksternal dengan Audit Judgement. Kualitas Judgement auditor sangat tergantung pada persepsi dari suatu situasi. Secara umum dapat disimpulkan bahwa auditor sebagai manusia tidak berorientasi pada probabilitas, biasanya mereka menyadarkan diri pada Judgement heuristic yang biasanya berasal dari pengalaman. Dalam Penelitian ini hasilnya tidak berpengaruh dikarenakan adanya asumsi bahwa Interlock auditor eksternal harus diimbangi dengan pengalaman yang mumpuni.

\section{KESIMPULAN DAN SARAN}

\subsection{Kesimpulan}

Penelitian ini mendapatkan hasil bahwa hanya variabel audit fee dan Independensi yang berpengaruh terhadap Audit Judgement dalam pendeteksian kecurangan Laporan Keuangan pada Kantor Akuntan Publik di Manado, karena dalam objek ini, responden menilai bahwa audit fee yang besar diakibatkan karena resiko serta reputasi KAP tersebut semakin tinggi, sehingga pemeriksaan mereka akan semakin baik pula, dan sikap independen, seorang auditor akan dituntun dalam pelaksanaan tugas yang berkualitas. Variabel Narsisme Klien, Skeptisme Profesional dan Interlock Auditor Eksternal tidak berpengaruh terhadap Audit Judgement dalam pendeteksian kecurangan Laporan Keuangan pada Kantor Akuntan Publik di Manado karena dalam objek ini, responden menilai bahwa sifat narsis dimiliki setiap orang dan dapat diarahkan ke hal yang positif, sedangkan skeptisme profesional dan interlock auditor eksternal harus semakin ditingkatkan baik dalam segi keahlian maupun pengalaman sehingga dapat membawa auditor lebih kritis dalam judgement auditnya.

\subsection{Saran}

1. Bagi Auditor, kiranya penelitian ini menjadi perhatian dalam pengembangan kualitas profesional mereka, karena melihat betapa pentingnya faktor-faktor ini untuk menaikkan kinerja pemeriksaan laporan keuangan serta keberlangsungan usaha suatu KAP.

2. Hasil penelitian ini dapat berbeda pada KAP di wilayah yang berbeda dengan tingkat pengalaman dan besar KAP yang berbeda pula. Namun terlepas dari signifikan tidaknya pengaruh faktor-faktor penelitian tersebut, kiranya penelitian ini boleh menjadi masukkan yang baik bagi pemutakhiran Kode Etik Profesional Akuntan.

3. Untuk penelitian selanjutnya, sebaiknya ditambahkan variabel pengalaman. Karena umumnya auditor sebagai manusia tidak berorientasi pada probabilitas, biasanya mereka menyadarkan diri pada Judgement heuristic yang biasanya berasal dari pengalaman.

\section{DAFTAR PUSTAKA}

Amemic, J. H., Craig, R. J., 2010. Accounting As A Facilitator Of Extreme Narcissism. Journal Of Business Ethics, Volume 96, Pp. 79-93. 
Arens, A. A., Elder, R. J., Beasley, M. S., 2014. Auditing And Assurance Services: An Integrated Approach. 15th Ed. Usa: Pearson.

Braam, G., Borghans, L. 2014. Board And Auditor Interlocks And Voluntary Disclosure In Annual Reports. Journal Of Financial Reporting And Accounting, 12(2), 135-160.

Hurtt, R. K., 2010b. Development Of A Scale To Measure Professional Skepticism. Auditing: A Journal Of Practice \& Theory, 29(1), Pp. 149-171.

Hurtt, K., Eining, M., Plumlee, R. D., 2010a. Linking Professional Skepticism To Auditors' Behaviors. Working Paper.

Irmawan, Tedy. 2011. Pengaruh Profesionalisme Dan Objektivitas Auditor Internal Terhadap Judgment Auditor Eksternal (Kajian Empiris Pada Kap Di Kota Semarang). Skripsi. Universitas Negeri Semarang. Semarang.

Johnson, E. N., Kuhn Jr, J. R., Apostolou, B. A. dan Hassel, J. M., 2013. Auditors Perceptions Of Client Narcissism As A Fraud Attitude Risk Factor. A Journal Of Practice \& Theory, 32(1), Pp. 203-219.

Koroy, Tri Ramaraya. 2008. Pendeteksian Kecurangan (Fraud) Laporan Keuangan Oleh Auditor Eksternal. Jurnal. Stie Nasional Banjarmasin.

Nelson, M. W., 2009. A Model And Literature Review Of Profesional Skepticism In Auditing. Auditing: Journal Of Practice \& Theory, 28(2), Pp. 1-34.

Purba, Fitriani Kartika. 2013. Pengaruh Fee Audit Dan Pengalaman Auditor Eksternal Terhadap Kualitas Audit. Jurnal. Fakultas Ekonomi Universitas Komputer Indonesia. Jakarta.

Rapina., Saragi, Lili Marlen., Carolina, Verani. 2010. Pengaruh Independensi Eksternal Auditor Terhadap Kualitas Pelaksanaan Audit (Studi Kasus Pada Beberapa Kantor Akuntan Publik Di Bandung). Jurnal. Akurat Jurnal Ilmiah Akuntansi No.2 Tahun Ke1 Mei-Agustus 2010. Universiras Kristen Maranatha. Surabaya.

Rijsenbilt, A., Commandeur, H., 2013. Narcissus Enters The Courtroom: Ceo Narcissism And Fraud. Journal Of Business Ethics, Volume 117, Pp. 413-429.

Sari, Rizki Aprilia Arista., Juliarto, Agung. 2016. Interlock Dewan Direksi, Interlock Auditor Eksternal Dan Pengaruhnya Terhadap Pengungkapan Sukarela. Jurnal. Universitas Diponegoro. Semarang.

Sukrisno Agoes. 2012. Auditing Petunjuk Praktis Pemeriksaan Akuntan Oleh Akuntan Publik. Salemba Empat. Jakarta.

Winardi, Rijadh Djatu., Permana, Yoga. 2015. Pengaruh Skeptisme Profesional Dan Narsisme Klien Terhadap Penilaian Auditor Eksternal Atas Risiko Kecurangan. Jurnal. Universitas Gadjah Mada. Yogyakarta. 